\title{
The Effect of Implementing the Financial Management Information System on the Quality of the Presentation of the Pangkep Regency Government's Financial Statements
}

\author{
Andi Sry Anggraeny ${ }^{1}$ \\ ${ }^{1}$ Accounting Department, Faculty of Economics and Business, Muhammadiyah University of \\ Makassar, Indonesia
}

\begin{tabular}{|c|c|}
\hline Article Info & Abstract \\
\hline & Purpose: This study aims to examine the effectiveness of the application of \\
\hline 020 & Government Accounting Standards to the quality of financial reports in the \\
\hline 2020 & local government of Pangkep Regency, Indonesia. \\
\hline Acc & $\begin{array}{l}\text { Approach/Methodology/Design: In this study, the sample taken was } 43 \\
\text { administrators from } 45 \text { Regional Work Units (SKPD) which consisted of a }\end{array}$ \\
\hline Keyw & financial statement drafting team and Regional Government Internal Auditors \\
\hline & (AIPD) involved in the preparation of Pangkep District Government's \\
\hline Government Accounting & financial statements. Data collection was carried out through direct \\
\hline $\begin{array}{l}\text { Standards, } \\
\text { Quality, }\end{array}$ & observation and surveys obtained by distributing questionnaires to the \\
\hline $\begin{array}{l}\text { Regional Government, } \\
\text { Financial Statements. }\end{array}$ & Findings: The results showed that the effectiveness of the application of \\
\hline $\begin{array}{l}\text { JEL: G32, H21, C33, H70, } \\
\text { H83. }\end{array}$ & $\begin{array}{l}\text { quality of local government financial reports. } \\
\text { Practical Implications: An important implication of the results of this study } \\
\text { is that the effectiveness of implementing a system is highly dependent on the }\end{array}$ \\
\hline Paper Type : & $\begin{array}{l}\text { achievement of the quality of the output it produces. That is, a program is said } \\
\text { to be successful if the program's objectives are effectively achieved. The }\end{array}$ \\
\hline Research Article & $\begin{array}{l}\text { amount of contribution greatly depends on the achievement of the targets and } \\
\text { targets that have been set. }\end{array}$ \\
\hline $\begin{array}{l}\text { Corresponding Author: } \\
\text { Andi Sry Anggraeny }\end{array}$ & $\begin{array}{l}\text { Originality/value: The regional management information system is part of the } \\
\text { state's efforts to present good governance, a government that can be } \\
\text { accountable for activities financed through measurable and transparent } \\
\text { public budgets. This paper examined the implementation of this system, and }\end{array}$ \\
\hline $\begin{array}{l}\text { Email: } \\
\text { anggazart@gmail.com }\end{array}$ & $\begin{array}{l}\text { it is concluded that it has a positive and significant effect on the quality of the } \\
\text { presentation of financial statements at the Pangkep Regency Government. }\end{array}$ \\
\hline
\end{tabular}

\section{Introduction}

Since regional autonomy was enacted in Indonesia, provincial and district/city regions as autonomous regions have been given the authority by the central government to regulate their own government. In the provisions of the applicable legislation, regions are given freedom to local governments to implement and regulate their own government. The authority granted must ultimately be accountable to the giver of authority and the community. Therefore, the local governments and all the Regional Work Units (SKPD) as budget users are required to prepare financial reports as a form of accountability for financial management. 
According to Presidential Instruction number 4 of 2011, BPKP, in this case the Deputy of Supervision for Regional Financial Implementation considers it necessary to facilitate Regional Governments in preparing their apparatus for change, encouraging the implementation of regional financial governance in accordance with applicable regulations, efficient, effective, transparent, accountable, and auditable.

So the regional government which is the executor of regional autonomy can present financial reports in a fair, transparent and accountable manner in order to improve the quality of the financial report of the regional government. To support this goal, the Deputy for Supervision of Regional Financial Administration has formed a task force for the development of a Regional Management Information System (SIMDA).

Management information system is a system that overall aims to present information far broader than accounting information that is historical (Widjayanto, 2001, p.21). Management information systems that always use electronic data processing technology, using computer technology, will increase the level of work efficiency. Furthermore, the management information system can communicate all the outputs generated from each subsystem which is then integrated into information needed for management in decision making.

Public sector organizations, especially government organizations, are entities that have the obligation to submit their financial reports to the public. The government is a public sector organization that provides services to the community and is a driving force and facilitator in the success of development in an area (Handayani, 2010).

Public sector organizations whose function is to provide services to the public must also be able to provide information systems that are interactive and oriented to the needs of the community. The purpose of public sector financial reporting is to provide information about the resources, allocation and use of financial resources. It also provides information about how an entity funds its activities and meets its cash needs, providing useful information to evaluate the entity's ability to finance its activities and fulfil its obligations and commitments. Moreover, the public sector financial reporting provides information about the financial condition of an entity and the changes that occur, evaluating the performance of the entity regarding service costs, efficiency, and achievement of objectives (Bastian, 2010, p.297).

In order to realize fast, precise, and accurate regional financial management practices, the Financial and Development Supervisory Agency (BPKP) has developed a computer application system that can process financial transaction data into financial reports that can be used at any time, namely the Regional Management Information System (SIMDA). A technology application-based system is developed to support the achievement of accountability for local governments both at the reporting level (SKPKD) and at the accounting level (SKPD). This application is expected to assist local governments in planning and budgeting, as well as implementing and administering the APBD and accountability for the Regional Revenue and Expenditure Budget (APBD). 
Based on the background described above, this study aims to investigate the implementation of the Regional Financial Management Information System in the Presentation of Regional Financial Statements in Pangkep Regency.

\section{Methodology and Procedures}

The type of this research is qualitative and the method employed for data is analysis simple regression analysis. This research was conducted at the SKPD of the Pangkep Regency Government which has used the Regional Financial Management Information System (SIMDA) application for a long time so that it is feasible to be the object of research. The period of the study is from May to June 2019.

\section{Variables}

Variables in this study include system quality (system quality), information quality (information quality), service quality (service quality) and user satisfaction. This study used a questionnaire as a research instrument adopted from Indra (2014) which consists of 3 parts, namely system quality, information quality, service quality and user satisfaction. The System is filled in or answered by users of the Regional Management Information System (SIMDA) finance. Operationalization of these variables is through the use an ordinal scale.

The population in this study were the government SKPDs in Pangkep Regency, while for the sample of this study were government SKPDs that had used the Regional Financial Management Information System (SIMDA) application. The sample of this study was 45 participants consisting of treasurers of SKPD or staff of the financial subdivision as users of the SIMDA application. The data collection techniques from this research are; (a) Observation, carried out by conducting direct observations on the object of research, namely SKPD Pangkep Regency Government; (2) Questionnaires, are a number of written statements used to obtain information from respondents in the sense of reports about their personal or known matters. The questionnaire was then distributed to respondents (employees) in the Pangkep District Government SKPD.

The data analysis technique used in this study is simple regression analysis, where the regression equation is as follows:

$$
\mathrm{Y}=\alpha+\beta . \mathrm{X}+\varepsilon
$$

Information:

Y: Regional Financial Report

$\alpha$ : Constant

$\beta$ : Regression Coefficient

$\mathrm{X}$ : Implementation of Regional Financial Management Information Systems

$\varepsilon$ : Error

In the data analysis and processing, several tests were carried out including data quality testing, classical assumption tests and hypothesis testing. Validity test is used to determine whether a questionnaire is valid or not. The significance test was carried out by comparing the calculated 
$r$ value with the $r$ table. If $r$ count $>r$ table and is positive, then the variable is invalid. Reliability testing is used to assess the consistency of objects and data, ensuring that instruments that are used multiple times to measure the same object will produce the same data. To test the reliability in this study, the internal consistency method is used with Croanbach's Alpha technique with the help of the SPSS program. If the Croanbach's Alpha value is getting closer to 1.00 , it can be said that the more reliable the instrument used is. In general, Croanbach's Alpha value below 0.60 indicates the instrument used is not good or not reliable. The normality test aims to test whether in the regression model the distracting or residual variables have a normal distribution. It is known that the $T$ and $F$ tests assume that the residual value follows a normal distribution. If this assumption is violated, the statistical test will be invalid for a small sample size.

Heteroscedasticity test aims to test whether in the regression model there is an inequality of variants from the residuals from one observation to another. If the variance of the residuals from one observation to another observation remains, it is called homoscedasticity and if it is different it is called heteroscedasticity. A good regression model is homoscedasticity or heteroscedasticity does not occur. Simple linear regression analysis technique is used to measure the effect of more than one independent variable on one dependent variable. In this study, simple linear regression analysis is used to determine the effect of CSR on Company Sustainability. The general equation for simple linear regression is:

$$
\begin{aligned}
& Y=a+b x \\
& \text { Where: } \\
& Y=(\text { Sustainability }) \\
& a=\text { constant } \\
& b=\text { regression coefficient } \\
& \mathrm{x}=(\mathrm{CSR})
\end{aligned}
$$

\section{Results and Discussion}

\section{a. SIMDA Implementation Variables $(\mathrm{X})$}

The regional financial management information system (SIMDA) implementation variable is measured by 5 indicators, namely the quality of input data, human resource competence, top management support, perceptions of system success, and SIMDA benefits.

\section{1) Presentation of input data quality indicator data}

The instrument used to measure indicators of the quality of input data is a questionnaire with 3 statement items on a Likert scale. The results are shown in the following table.

Table 1: Descriptive Statistics of Input Data Quality Indicators

\begin{tabular}{|c|c|c|c|c|c|c|}
\hline \multirow{2}{*}{ Item } & \multicolumn{5}{|c|}{ Answer Choice (\%) } & \multirow{2}{*}{ Mean } \\
\cline { 2 - 6 } & 5 & 4 & 3 & 2 & 1 & \\
\hline $\mathrm{X} 1.1$ & 48,84 & 46,51 & 2,33 & 2,33 & - & 4,42 \\
\hline
\end{tabular}




\begin{tabular}{|r|r|r|r|r|r|r|}
$\mathrm{X} 1.2$ & 20,93 & 62,79 & 13,95 & 2,33 & - & 4,02 \\
\hline $\mathrm{X} 1.3$ & 6,98 & 55,81 & 27,91 & 9,30 & - & 3,60 \\
\hline \multicolumn{7}{|c|}{ Mean Indicator } \\
\hline
\end{tabular}

Source: Results of questionnaire processing, 2019

Based on the table above, it can be seen that the average or mean value of the input data quality indicator is 4.02 (good category) with the answer mode in the agree (4) and strongly agree (5) category. If you look at the value of each measured item, it can be seen that one item with a value exceeding the mean of the indicator is the statement item (X1.1) "The input data used in financial reports is valid data" which has a mean value of 4.42 and the mode of answer in the category strongly agree. Meanwhile, one statement item with the mean value is below the mean of the indicator, namely item X1.3 "The input data used is available in sufficient quantities" with a mean value of 3.60 .

This situation illustrates that in general the respondents appreciate the quality of the input data from SIMDA although there are still things that need to be optimized, namely the availability of sufficient data when reporting will be prepared.

\section{2) Presentation of human resource competency indicator data}

The instrument used to measure the indicators of human resource competence is a questionnaire with 3 statement items on a Likert scale. The results are shown in the following table.

Table 2: Descriptive Statistics of Human Resource Competency Indicators

\begin{tabular}{|c|c|c|c|c|c|c|}
\hline \multirow{2}{*}{ Item } & \multicolumn{5}{|c|}{ Answer Choice (\%) } & \multirow{2}{*}{ Mean } \\
\cline { 2 - 6 } & 5 & 4 & 3 & 2 & 1 & \\
\hline X2.1 & 13,95 & 58,14 & 18,60 & 9,30 & - & 3,77 \\
\hline X2.2 & 4,65 & 55,81 & 27,91 & 9,30 & 2,33 & 3,51 \\
\hline X2.3 & 11,63 & 46,51 & 20,93 & 20,93 & - & 3,49 \\
\hline \multicolumn{7}{|c|}{ Mean Indicator } \\
\hline
\end{tabular}

Source: Results of questionnaire processing, 2019

Based on the table, it can be seen that the average or mean value of the human resource competency indicator is 3.59 (good category) with the answer mode in the agree category (4). When examining the value of each item being measured, it can be seen that one item with a value exceeding the mean of the indicator, namely the statement item (X2.1) "Basic, intermediate and upper level training in the SIMDA training program is well implemented" has a mean value of 3.77 and the answer mode in the agree category. Nevertheless, 2 items of statement with values are below the indicator mean i.e. item X2.2 "The SIMDA training program for employees in my agency is carried out in good frequency" and X2.3 "The length of time working in a field that uses SIMDA in sufficient quantities".

This situation illustrates that although in general respondents appreciate the competence of human resources well, there are several aspects that need to be improved, namely increasing the frequency of SIMDA training activities and experience in SIMDA implementation. 


\section{3) Presentation of top management support indicator data}

Top management support indicators are measured using a Likert scale questionnaire with a statement item. The results can be seen in the following table.

Table 3: Descriptive Statistics of Top Management Support Indicators

\begin{tabular}{|c|c|c|c|c|c|c|}
\hline \multirow{2}{*}{ Item } & \multicolumn{5}{|c|}{ Answer Choice (\%) } & \multirow{2}{*}{ Mean } \\
\cline { 2 - 5 } & 5 & 4 & 3 & 2 & 1 & \\
\hline X3.1 & 53,49 & 39,53 & 6,98 & - & - & 4,47 \\
\hline X3.2 & 32,56 & 51,16 & 16,28 & - & - & 4,16 \\
\hline X3.3 & 30,23 & 30,23 & 39,53 & - & - & 3,91 \\
\hline \multicolumn{5}{|c|}{ Mean Indicator } & 4,18 \\
\hline
\end{tabular}

Source: Results of questionnaire processing, 2019

Based on the table, it can be seen that the average value or the mean indicator of top management support is 4.18 (good category). If you see the value of each item measured, it can be seen that there is one item with a value below the indicator mean value, namely the statement item (X3.3) "Top management follows every development of the latest SIMDA application" has a mean value of 3.91 and an answer mode in the neutral category (3). Meanwhile, 2 statement items with a value above the mean indicator are item X3.1 "Top management evaluates the results of using SIMDA" and X3.2 "Top management pays attention to the use of SIMDA".

This situation illustrates that although in general the respondents appreciate the support of top management well, there are points that need to be improved, namely the socialization of SIMDA developments by top management to employees.

\section{4) Presentation of data on perceptions of system success indicators}

Perceptions of system success are measured by 3 statement items, namely the use of SIMDA information in the budgeting process, the budgeting process, and the perception of SIMDA as a good tool in budgeting. For more details, the results of the descriptive analysis are shown in the following table.

Table 4: Descriptive Statistics of Perceptions of System Success Indicators

\begin{tabular}{|c|c|c|c|c|c|c|}
\hline \multirow{2}{*}{ Item } & \multicolumn{5}{|c|}{ Answer Choice (\%) } & \multirow{2}{*}{ Mean } \\
\cline { 2 - 6 } & 5 & 4 & 3 & 2 & 1 & \\
\hline X4.1 & 32,56 & 53,49 & 13,95 & - & - & 4,19 \\
\hline X4.2 & 16,28 & 67,44 & 16,28 & - & - & 4,00 \\
\hline
\end{tabular}




\begin{tabular}{|l|l|l|l|l|l|l|} 
X4.3 & 53,49 & 39,53 & 6,98 & - & - & 4,47 \\
\hline \multicolumn{3}{|c|}{ Mean Indicator } & 4,22 \\
\hline
\end{tabular}

Source: Results of questionnaire processing, 2019

Based on the table, it can be seen that the average or mean value of the perceived success indicator of the system is 4.22 (good category). If you look at the value of each item measured, there are two items with values below the mean value of the indicator, namely the statement item (X4.1) "The overall benefits of the information system that you use in the budget process also consider the cost" has a mean value of 4,19 and the answer mode in the agree category (4) then the statement item (X4.2) "The budget process is a good tool for managing regional finances" with a mean value of 4.00 and the answer mode in the agree category (4). Whereas 1 item statement with a value above the indicator mean is item X4.3 "The information system you use in the budget process is a good tool for managing regional finances".

This situation illustrates that although in general respondents appreciate the success of SIMDA, there are still things that need to be optimized, namely the full use of SIMDA in the budgeting process and financial management.

\section{5) Presentation of SIMDA benefit indicator data}

The instrument used to measure the indicators of SIMDA benefits is a questionnaire with 4 statement items on a Likert scale, namely the ease of SIMDA implementation, data processing with SIMDA can carry out accounting procedures correctly and carefully, the system can produce quarterly, monthly, and annual reports when needed, and Implementation SIMDA creates efficiency and effectiveness at work. The results are shown in the following table.

Table 5: Descriptive Statistics of SIMDA Benefit Indicators

\begin{tabular}{|c|c|c|c|c|c|c|}
\hline \multirow{2}{*}{ Item } & \multicolumn{7}{|c|}{ Answer Choice (\%) } & \multirow{2}{*}{ Mean } \\
\cline { 2 - 6 } & 5 & 4 & 3 & 2 & 1 & \\
\hline X5.1 & 34,88 & 55,81 & 9,30 & - & - & 4,26 \\
\hline X5.2 & 44,19 & 25,58 & 30,23 & - & - & 4,14 \\
\hline X5.3 & 39,53 & 53,49 & 6,98 & - & - & 4,33 \\
\hline X5.4 & 32,56 & 60,47 & 6,98 & - & - & 4,26 \\
\hline \multicolumn{7}{|c|}{ Mean Indicator } \\
\hline
\end{tabular}

Source: Results of questionnaire processing, 2019

Based on the table, it can be seen that the average or mean value of the SIMDA benefit indicator is 4.24 (good category) with the answer mode in the agree category (4). If we look at the value of each measured item, it can be seen that one item with a lower value than the mean value of the indicator, namely the statement item X5.2 "Data processing with SIMDA can carry out accounting procedures correctly and accurately" has a mean value of 4.14. The other 3 items were well appreciated exceeding the average value of the indicators. 
This situation illustrates that although in general respondents appreciate the benefits of SIMDA, there are things that need to be improved, namely the accuracy of the information in SIMDA so that there are no more mistakes in decision making. The expectations of internal users in local governments are well aware that even though this information system has been implemented and utilized, it does not rule out errors, especially in the accuracy of the information entered in the system. Errors in input will cause the output in the form of financial reports to be incorrect so that the accuracy of the information collected into the initial raw materials to be processed at the next stage must be completely valid.

\section{6) Presentation of SIMDA Implementation Variable data}

The SIMDA implementation variable is obtained from 5 indicators as described previously. The descriptive statistics of SIMDA implementation variables are shown in the following table.

Table 6: Descriptive Statistics of SIMDA Implementation Variables based on each Indicator.

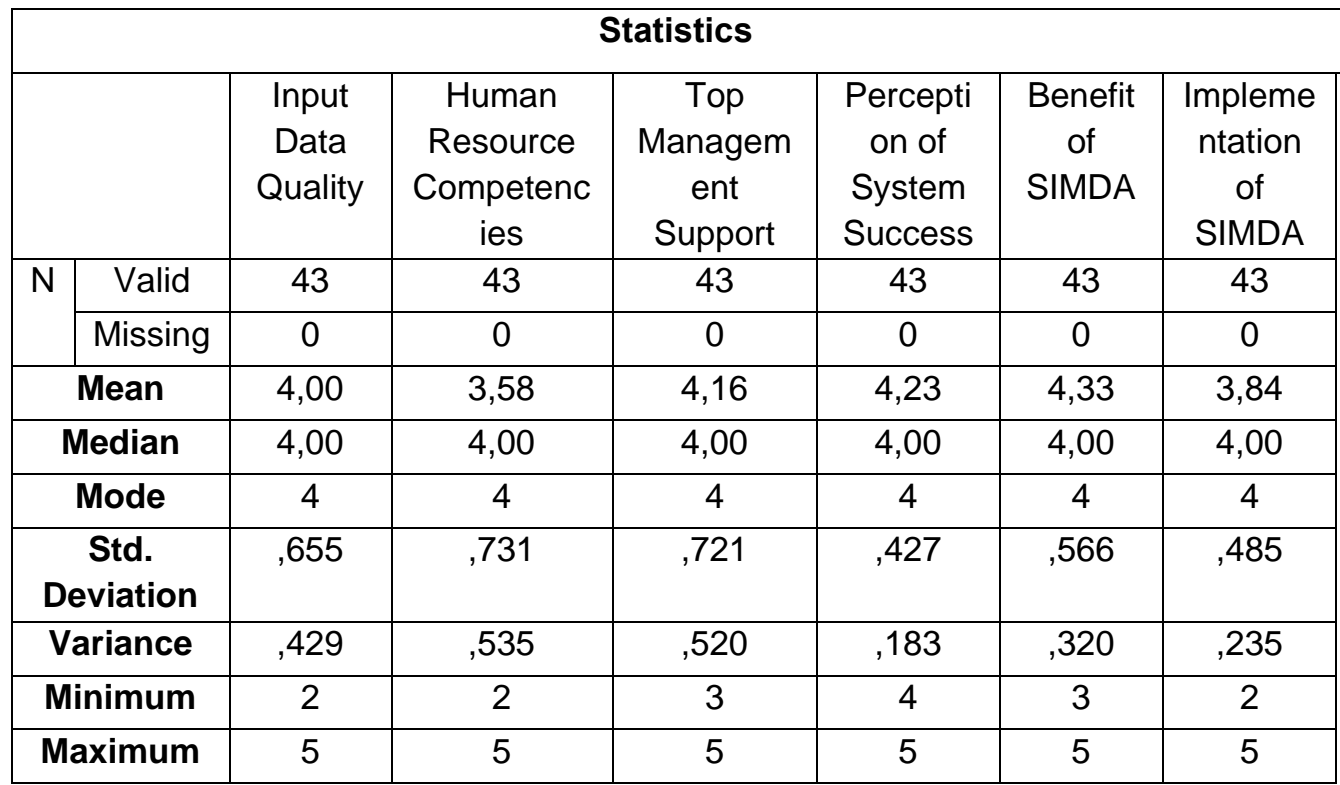

Source: Questionnaire Processing Results, 2019

Based on the results of data processing, it can be seen that the average value of the SIMDA implementation variable is 3.84 (good category) which is formed from 5 measurable indicators. The average value of each indicator varies, in general it is above the average value of the variable, but there is one indicator with an average value below the average value of the variable, namely the human resource competency indicator.

It seems that human resource competence is still an indicator that still needs improvement. Of course this is reasonable because the implementation of the regional financial management information system is new and needs to be updated from time to time. This is what causes the need to support regular training activities and involve all personnel who are directly involved in the use of SIMDA.

\section{b. Variable Quality of Financial Statement Presentation (Y)}


The instrument used to measure the variable quality of financial statement presentation is a Likert scale questionnaire with 4 statement items representing the 4 indicators used, namely the completeness of information in the financial statements, the information in the financial statements is not multiple interpretations and without errors, the use of Government Accounting Standards guidelines, and the information produced in clear and understandable financial statements. The results of measuring the quality variable in the presentation of financial statements are shown in the following table.

Table 7: Descriptive Statistics of Variable Quality of Financial Statement Presentation

\begin{tabular}{|c|c|c|c|c|c|c|}
\hline \multicolumn{7}{|c|}{ Statistics } \\
\hline & & $\begin{array}{l}\text { Y1.1 } \\
\end{array}$ & Y1.2 & Y1.3 & $\mathrm{Y} 1.4$ & $\begin{array}{c}\text { Financial } \\
\text { Report } \\
\text { Quality }\end{array}$ \\
\hline \multirow[t]{2}{*}{$\mathrm{N}$} & Valid & 43 & 43 & 43 & 43 & 43 \\
\hline & Missing & 0 & 0 & 0 & 0 & 0 \\
\hline \multicolumn{2}{|c|}{ Mean } & 3,98 & 3,63 & 3,35 & 3,63 & 3,72 \\
\hline \multicolumn{2}{|c|}{ Median } & 4,00 & 4,00 & 4,00 & 4,00 & 4,00 \\
\hline \multicolumn{2}{|c|}{ Mode } & 5 & 4 & 4 & 4 & 4 \\
\hline \multicolumn{2}{|c|}{ Std. Deviation } & 1,012 & ,874 & 997 & 1,024 & ,797 \\
\hline \multicolumn{2}{|c|}{ Variance } & 1,023 & ,763 & ,994 & 1,049 & ,635 \\
\hline \multicolumn{2}{|c|}{ Minimum } & 2 & 1 & 1 & 1 & 1 \\
\hline \multicolumn{2}{|c|}{ Maximum } & 5 & 5 & 5 & 5 & 5 \\
\hline
\end{tabular}

Source: Questionnaire Processing Results, 2019

Descriptive statistical data as shown in table 7 shows that the average value of the variable quality of financial statement presentation is 3.72 (good category). However, there is only one indicator that has a value that exceeds the average value of the variable, namely the indicator of completeness of information in the financial statements (Y1.1) with an average value of 3.98 while the other three indicators have an average value below the average value. -variable mean.

Thus it can be said that the quality of the presentation of financial statements in general is already good but several aspects still need to be optimized because the level of appreciation based on the perceptions of respondents in this study still needs to be addressed. This includes information in the financial statements that still has the potential for multiple interpretations and causes errors, the use of Government Accounting Standard guidelines has not been fully adopted, and the information generated in the financial statements is sometimes unclear and so it is not well understood by other parties.

\section{Hypothesis test}

To test the hypothesis, data processing was carried out using simple linear regression. The results of data processing are shown in the following table.

Table 8: Regression Coefficients

\section{Coefficients}




\begin{tabular}{|c|c|c|c|c|c|}
\hline \multirow[t]{2}{*}{ Model } & \multicolumn{2}{|c|}{$\begin{array}{l}\text { Unstandardized } \\
\text { Coefficients }\end{array}$} & $\begin{array}{l}\text { Standardize } \\
\mathrm{d} \\
\text { Coefficients }\end{array}$ & $\mathrm{t}$ & Sig. \\
\hline & B & Std. Error & Beta & & \\
\hline (Constant) & $\begin{array}{r}- \\
1.35 \\
6\end{array}$ & 0.589 & & 2.301 & $\begin{array}{r}0.02 \\
7\end{array}$ \\
\hline $\begin{array}{l}\text { Implementation of } \\
\text { SIMDA }\end{array}$ & $\begin{array}{r}1.32 \\
3\end{array}$ & 0.152 & 0.805 & 8.682 & $\begin{array}{r}0.00 \\
0\end{array}$ \\
\hline
\end{tabular}

Because the value is positive, the relationship between variable $\mathrm{X}$ and variable $\mathrm{Y}$ is unidirectional, which means that if there is an increase in the implementation of the regional financial management information system, it is estimated that it will cause an increase in the quality of regional financial reports, assuming other things are constant or unchanged.

Table 9: Significance Test

\begin{tabular}{|c|c|c|c|c|c|}
\hline \multicolumn{6}{|c|}{ ANOVA $^{a}$} \\
\hline Model & $\begin{array}{l}\text { Sum of } \\
\text { Squares }\end{array}$ & df & $\begin{array}{c}\text { Mean } \\
\text { Square }\end{array}$ & $\mathrm{F}$ & Sig. \\
\hline $\begin{array}{l}\text { Regressio } \\
n\end{array}$ & 17.262 & 1 & 17.262 & 75.379 & $.000^{b}$ \\
\hline Residual & 9.389 & 41 & .229 & & \\
\hline Total & 26.651 & 42 & & & \\
\hline \multicolumn{6}{|c|}{ a. Dependent Variable: Quality of Financial Statements } \\
\hline b. Predictors: ( & SIMDA Ir & tatio & & & \\
\hline
\end{tabular}

The significance value is indicated by the Sig column. with a value of 0,000 . This value is much smaller than alpha 0.05. Alpha 0.05 is a tolerable error level which means that the regression model in this study has a prediction error rate of $5 \%$ or a confidence level of $95 \%$. The results of this analysis indicate that the variable implementation of the regional financial management information system has a positive and significant effect on the quality of the presentation of regional financial reports in Pangkep Regency.

Table 10: Correlation and Research Model Determination

\begin{tabular}{|c|c|c|c|c|}
\hline \multicolumn{5}{|c|}{ Model Summary } \\
\hline Model & $\mathrm{R}$ & $\mathrm{R}$ Square & $\begin{array}{c}\text { Adjusted R } \\
\text { Square }\end{array}$ & $\begin{array}{c}\text { Std. Error of the } \\
\text { Estimate }\end{array}$ \\
\hline 1 & $.805^{\mathrm{a}}$ & .648 & .639 & .479 \\
\hline Predictors: (Constant), Implementation of SIMDA \\
\hline
\end{tabular}

The coefficient of determination in the processing result table shows an $\mathrm{R}$ Square value of 0.648 which means that the effect of the implementation of the regional financial management 
information system on the quality of the presentation of regional financial statements in Pangkep Regency is $64.8 \%$ while the remaining $35.2 \%$ is contributed by other variables that are not included in the research model.

The results of the regression analysis showed that the implementation of the regional financial management information system had a positive and significant effect on the quality of the presentation of the Pangkep local government financial statements. The results of this study are in line with the benefits of information systems according to DeLone and McLone (2003), that a system can be evaluated in terms of information quality, system quality, and service quality. These three characteristics affect the use or intention to use and user satisfaction with system usage. One of the goals of developing a regional management information system is that the quality of the presentation of regional financial reports can provide satisfaction to stakeholders who use the report.

The financial statements prepared by the local government are the accountability for the utilization of economic resources owned by the local government. Therefore, the quality of its presentation must be carried out in such a way that the public as the principal (legal owner) of these economic resources can obtain accurate, clear, unambiguous information, and give confidence that the government manages economic resources that are properly mandated, transparent, and accountable.

The results of this study are in accordance with the results of research conducted by Abidin, Afifudin and Junaidi. (2018), Primasari (2017), Ole, H. R. (2014), and Hertanto, Y., Domai, T., \& Amin, F. (2017). This illustrates the consistency of the previous findings with the results of this study, which means that with a more expanded object, the regional management information system turns out to be one of the main supporters of the birth of local government financial reports whose presentation provides information that is clear and easily understood by users.

The regional management information system is part of the state's efforts to present good governance, a government that can be accountable for activities financed through measurable and transparent public budgets. SIMDA is one of the products of the application of eGovernment principles that began to emerge when the Presidential Instruction No. 3/2003 was issued, namely the National Strategy for e-Government Development, which was then supported by the emergence of Permendagri No. 59/2007 concerning Amendment to Regulations on Ministerial Regulation No. 13 The year 2006 is about the Regional Financial Management Guidelines concerning the Regional Financial Management Guidelines. This management information system was developed to facilitate work unit activities in managing their finances, so that in the end the work unit's financial management becomes more effective, efficient and economical.

An important implication of the results of this study is that the effectiveness of implementing a system is highly dependent on the achievement of the quality of the output it produces. That is, a program is said to be successful if the program's objectives are effectively achieved. The amount of contribution greatly depends on the achievement of the targets and targets that have 
been set. Gibson (2011) explains that there are 3 forms of effectiveness, including (1) the most basic level is individual effectiveness, which emphasizes individual results in the organization, (2) group effectiveness, and (3) organizational effectiveness. To ensure this, the source of financial report data must be valid, accurate, timely and presented in forms suitable for each level of management. Therefore, in meeting the objectives of financial statements, this process must be well developed, especially at each level of management at the entire organization. As according to Hamilton (1985) Effective financial statements require criteria: 1) Trustworthy, 2) Accuracy, 3) Timely, 4) Forms of report.

\section{Conclusion and Suggestion}

Based on the results of data analysis and hypothesis testing, it can be concluded that the implementation of the regional management information system has a positive and significant effect on the quality of the presentation of financial statements at the Pangkep Regency Government. The relationship between the two variables marked positive (unidirectional) which means the better the implementation of the regional management information system, the better the quality of the presentation of the financial statements of the local government. The predictive power of the model as shown by the coefficient of determination shows that $64.8 \%$ of the changes in the quality of financial statement presentation can be predicted by the model at an error rate of $5 \%(\alpha=0.05)$ or at a $95 \%$ confidence level.

\section{Conflict of Interest}

The author of the article declares no conflict of interest.

\section{Funding}

This research study was not funded by any institution. The author conducted the study on his own expenses.

\section{References}

Anthony, N., Robert dan Govindarajan, Management Control System.

Hartati, Yenni. (2011). Analisa Pengungkapan Laporan Keuangan Opini Wajartanpa Pengecualian, (Online), (http://pasca.unand.ac.id,Diakses24 Juni2013).

Ikhtisar Hasil Pemeriksaan Semester II Tahun 2012-.2013. Jakarta: BadanPemeriksa Keuangan Negara.

Irwana, Toni. (2010). Pengaruh Efektivitas Penerapan Standar AkuntansiPemerintahan Terhadap Kualitas Laporan Keuangan: Penelitian pada Pemerintah Kabupaten/Kota di Wilayah PrianganJawa Barat. Bandung:Program Studi Universitas Pendidikan Indonesia.

Jannaini, Yuli. (2012). Pengaruh Penerapan Standar Akuntansi Pemerintahanterhadap Kualitas Laporan Keuangan dan Implikasinya terhadap Akuntabilitas Pemerintah Daerah. Bandung: Program Studi UniversitasKomputer Indonesia. 
Kiswara, Endang. (2011). Analisis pengaruh Kualitas Primer Nilai Relevan danKualitas Primer Reliabilitas terhadap kegunaan keputusan informasi akuntansi menurut metode-metode pembebanan pajak penghasilan yang berbeda dan implikasinya terhadap penyajian laporan keuangan. Tesis tidak diterbitkan.Semarang: Program Pasca Sarjana Fakultas Ekonomi Universitas Diponegoro.

Moeller dan Robert. (2009). Brink's Modern Internal Auditing: A Common Body Of Knowledge. USA: Electronic Book.

Nurlaela, Sitti dan Rahmawati. (2010). Pengaruh Faktor Keperilakuan OrganisasiTerhadap Kegunaan Sistem Akuntansi Keuangan Daerah di Subosukawonosrate. 13: 1-38.

Republic of Indonesia Government Regulation Number 60 of 2008 concerning Government Internal Control.(2009). Jakarta: KomitePengendalianIntern.

Republic of Indonesia Government Regulation Number 71 of 2010 concerning Government Accounting Standards. (2011). Jakarta: Komite StandarAkuntansi Pemerintahan.

Permana, Irvan. 2011. Pengaruh Penerapan Standar Akuntansi Pemerintahanterhadap Kualitas Laporan Keuangan Pemerintah Daerah dan Implikasinya Akuntabilitas. Bandung: Program Studi UniversitasKomputer Indonesia.

Santoso,Urip dan Pambelum, Joni, Yohanes. (2008). Pengaruh Penerapan Akuntansi Sektor Publik terhadap Akuntabilitas Kinerja Instansi Pemerintah Dalam Mencegah Fraud. Jurnal Administrasi Bisnis, (Online), Vol. 4, No.1, (Http://journal.unpar.ac.id/index.php/JABCebis/article/view/ 50/40, diakses 23 Januari 2014).

Sekaran, Uma dan Bougie, Roger. (2009). Research Methods for Business: A Skill Building Approach (Edisi 5). Great Britain: TJ International Ltd, Padstow,Cornwall.

Sugiyono. (2011). Metode Penelitian Kuantitatif, Kualitatif, dan $R \&$ D. Bandung: Alfabeta. Terjemahan oleh Drs. F.X. Kurniawan Tjakrawala, M.si., Akt..2005.Jakarta: Salemba Empat. 